\title{
INVESTIGATION OF FACTORS, DETERMINING DISPERSITY OF COATING PARTICLES AT ARC SPUTTERING WITH PULSATING SPRAYING STREAM
}

\author{
Vyacheslav Royanov \\ Doctor of Technical Sciences, Professor, Department of Automation and Mechanization of Welding \\ Production, State Higher Educational Institution «Priazovskiy State Technical University», Mariupol, \\ Ukraine, ORCID ID: https://orcid.org/0000-0001-5379-9096
}

\begin{abstract}
Irina Zakharova
PhD, Associate Professor, Department of Automation and Mechanization of Welding Production, State Higher Educational Institution «Priazovskiy State Technical University», Mariupol, Ukraine, ORCID ID: http://orcid.org/0000-0002-3492-0134
\end{abstract}

\begin{abstract}
Mykyta Kriuchkov
Graduate student, Department of Automation and Mechanization of Welding Production, State Higher Educational Institution «Priazovskiy State Technical University», Mariupol, Ukraine, ORCID ID: https://orcid.org/0000-0003-1012-0156
\end{abstract}

\section{Valeriy Chigarev}

Doctor of Technical Sciences, Professor, Department of Automation and Mechanization of Welding Production, State Higher Educational Institution «Priazovskiy State Technical University», Mariupol, Ukraine, ORCID ID: https://orcid.org/0000-0002-1480-2261

\section{DOI: https://doi.org/10.31435/rsglobal_ws/30062020/7099}

\section{ARTICLE INFO}

Received: 14 April 2020

Accepted: 19 June 2020

Published: 30 June 2020

\section{KEYWORDS}

mass of liquid metal, parameters of the electric arc mode, pulsating air flow, sprayed surface.

\begin{abstract}
The essence of the process of electric arc spraying, consists in melting the electrodes with an electric arc and continuous separation of the liquid metal formed at the ends of the electrodes, a stream of compressed air and dispersing it on the sprayed surface

To use the periodic removal of pulsating air flow of liquid metal from the ends of the electrodes, it is important to solve the problem of guaranteeing the exclusion of short circuits of electrodes in the complete absence of spray flow and constant continuous supply of electrodes to the combustion zone of the arc. short circuit and when the spray flow is turned on after a pause will ensure the separation and transportation of liquid metal from the ends of the electrodes on the sprayed surface.

It is important to determine the optimal mass of liquid metal and the time of formation of a drop of liquid metal depending on the technological parameters of the sprayed electrodes and the energy level of the arc that melts the electrodes.

Studies of the determining factors of this process, namely the parameters of the electric arc mode, diameter, material and feed rate of the electrodes are presented.
\end{abstract}

Citation: Vyacheslav Royanov, Irina Zakharova, Mykyta Kriuchkov, Valeriy Chigarev. (2020) Investigation of Factors, Determining Dispersity of Coating Particles at Arc Sputtering with Pulsating Spraying Stream. World Science. 6(58), Vol.1. doi: 10.31435/rsglobal_ws/30062020/7099

Copyright: (C) 2020 Vyacheslav Royanov, Irina Zakharova, Mykyta Kriuchkov, Valeriy Chigarev. This is an open-access article distributed under the terms of the Creative Commons Attribution License (CC BY). The use, distribution or reproduction in other forums is permitted, provided the original author(s) or licensor are credited and that the original publication in this journal is cited, in accordance with accepted academic practice. No use, distribution or reproduction is permitted which does not comply with these terms.

A method of electric-arc sputtering with a pulsating spraying air flow was developed at the department of Automation and mechanization of welding production of Priazovskyi State Technical 
University. The method's principle was described in previous works and the results of investigation of technological characteristics, a substantial decrease of spraying air consumption was reasoned, as well as reduction of alloying elements losses in the coating at electrode materials sputtering.

However, the data regarding the influence of the main factors upon the particles dispersity of the sputtered materials are still missing. This article proposes an analytical evaluation of the mass of dispersed particles at electric-arc sputtering with pulsating spraying flow, with regard to the adjusted Electric arc metallization (hereinafter EAM) [5] diagram, also noted was the leading influence of electric arc energy upon the particles dispersity.

Figure 1 represents the evaluated diagrams of the forces, acting upon the liquid metal of electrodes at electric-arc sputtering.

Figure $1 a$-is the diagram for the cases with maximum action of the spraying flow at EAM, in accordance with $[11,12]$ data, when

$$
\overleftarrow{F}_{s t .} \leq \vec{F}_{j}+\vec{F}_{e l .} .
$$

where $F_{s t}-$ is the force of surface tension of liquid metal;

$F_{e l}$-the electrodynamic force;

$F_{j}$ - the force of dynamic action of gas jet upon the liquid metal.
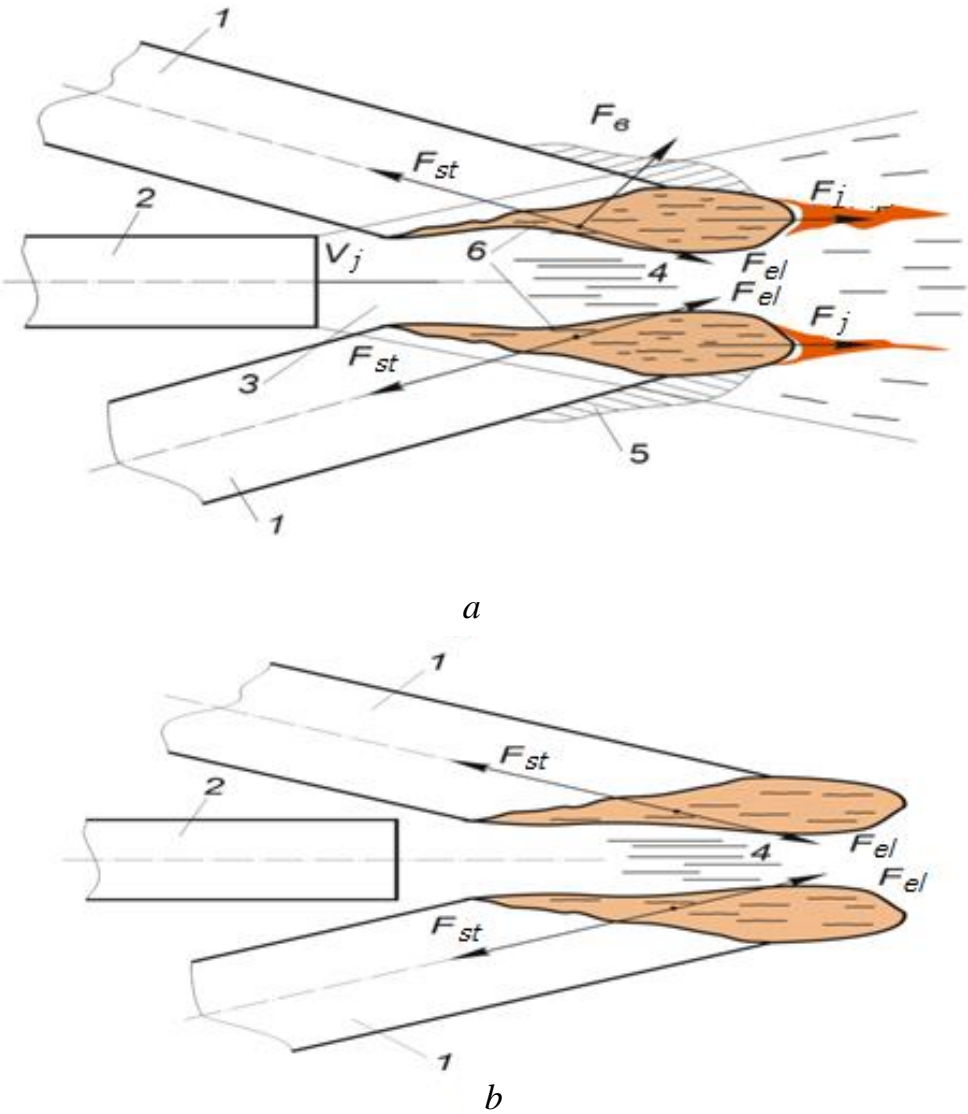

Fig. 1. The diagram of electrodes acting upon the liquid metal at pulsating injection of the spraying flow. $a$-jet action; $b$-absence of jet action

1 -sputtered electrodes, 2 - air jet; 3 -spraying air jet; 4 -electric arc; 5 -turbulence (depression) area; 6 -liquid metal on electrodes butts; 7 -interelectrode space; 8 -particles of sputtered metal.

$F_{s t}$ - is the surface tension force; $F_{e l}$ - the electrodynamic force; $F_{j}$ - the force of gas jet acting upon the liquid metal; $F_{b}$ - the force of turbulence (depression) action at electrodes streamlining by the gas jet.

In case of absence of jet action (see Fig. 1b) the following forces action at removal of emerging liquid metal from the surface of electrodes butts takes place:

$$
\overleftarrow{F}_{s t} \leq \vec{F}_{e l .} .
$$


The aggregate correlation of forces, acting upon the liquid metal of electrodes butts at pulsating spraying operation flow [7] is represented by the expression (3):

$$
F_{p}=\vec{F}_{\text {sep. }}+\vec{F}_{\text {el. }}+\overleftarrow{F}_{s t}
$$

or for the condition with removal of liquid metal from electrodes butts

$$
F_{p}=\overleftarrow{F}_{s t}-\left(\vec{F}_{e l .}+\vec{F}_{s e p .}\right)
$$

Now, let us consider the action of forces upon the liquid metal for the case when the action of the spraying jet at the interval is absent. We shall determine the value of the force of surface tension. According to the data provided by B.E. Paton and P.P. Sheyko [7] the value of the force of surface tension for ball surface of a drop on the electrode's butt can be determined from equation by means (5):

$$
F_{\text {st. }}=\frac{2 G}{R_{\text {cur }}} \pi R_{e l}^{2}
$$

where $R_{\text {cur }}-$ is the radius of curvature of the surface of the drop, in $\mathrm{cm}$,

$R_{e l}^{2}-$ the electrode radius, $\mathrm{cm}$

$G$ - the value of surface tension, $\mathrm{cm}$

The value of surface tension $G$ is reduced nearly linearly with the temperature, turning into zero at the critical temperature and can be determined according to Etvesh's formula. According to the data provided in the work [7] with regard to the electromagnetic system, formed by electrode stick-out distance and the arc column:

$$
F_{s t .}=2,1 \frac{\left(T_{c r}-T\right)}{\left(\mu \cdot \frac{1}{\gamma}\right)^{2 / 3}}
$$

where $T_{c r}$ - is metal critical temperature, ${ }^{\circ} \mathrm{K}$ (is determined by Humberg's collapse $T_{c r}=32 \mathrm{~T}_{\text {kin }}$ )

$T$ - metal temperature at a particular time instant, ${ }^{\circ} \mathrm{K}$

$\gamma$ - metal specific gravity $\mathrm{g} / \mathrm{cm}^{3}$

$\mu \cdot-$ metal molecular weight.

Taking into account the main regularities of electrodes melting at electric-arc welding and arc metallization and also the results, obtained by the authors in [5,6], it is possible to maintain that the liquid metal at electrodes melting is formed due to arc's power parameters and it moves, under the action of forces towards the electrodes butts with subsequent sputtering by the gas jet. The photographs of electrodes butts, pictured in Figure 2 at a momentary stoppage of the electric arc action allow us to maintain that the liquid on the electrodes butts possesses the shape close to semi-ellipsoid.

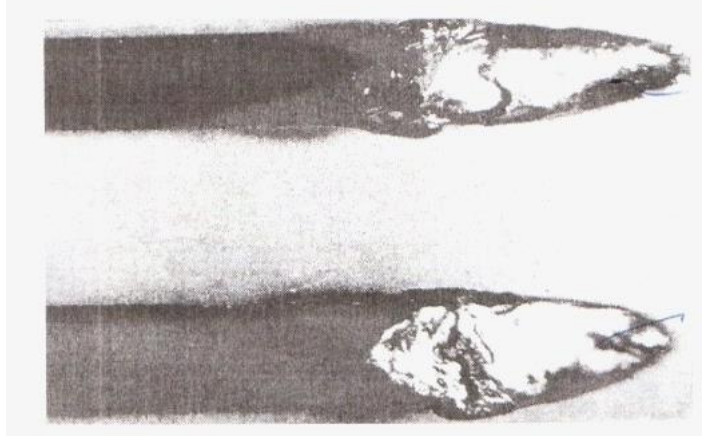

Fig. 2. The character of electrodes butts meltback at arc metallization with solid wire Co-08Г2C, $2 \mathrm{~mm}$ in diameter;

1 - liquid metal on electrode butt - the anode; 2 - liquid metal on electrode butt -the cathode

With due regard to the described above an analytical electromagnetic model with steel electrode and electric arc is proposed in Figure 3. 


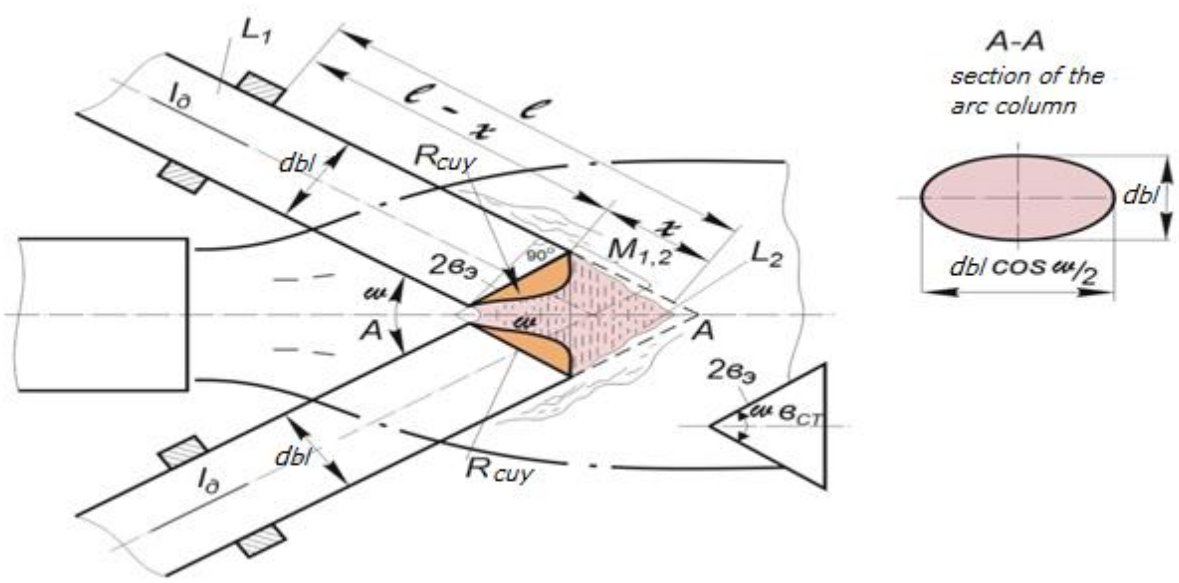

Fig. 3. Electromagnetic analytical model, formed by electrodes and the arc column.

$I_{c B}-i s$ the welding current, $L_{1}, L_{2}$-self-inductances, $M_{1,2}-$ mutual inductance $d_{e l}$-electrode's diameter, $d_{c m}$ - arc column diameter, $B_{c m}$ - the bigger half-axle of the arc column, $R_{\text {cuy }}$-radius of the electrode's butt curvature, $l$-electrode stick-out distance, $x$-arc length. .

On the basis of measuring of the parameters of electrodes butts after a momentary stoppage of spraying and the analysis of the films of rapid shooting it was found that the value of $\theta$ could vary within the limits of $\varepsilon \approx \mathrm{d}_{\mathrm{bl}} \ldots 2 \mathrm{~d}_{\mathrm{bl}}$, see the diagram in Figure 4.

The value of the half-axle of semi-ellipsoid is variable and depends upon the rate of electrode's melting and the electrode's material [7].

The value of the surface tension force, acting upon the liquid metal on the butt of the electrode at electric-arc metallization is determined from the expression below, with regard to [5 and 6]

$$
F_{s t .}=\frac{4,2 \cdot\left(T_{c r}-T\right) \cdot F_{s e c}}{\left(\mu \cdot \frac{1}{\gamma}\right)^{2 / 3} \cdot R_{c u r}}
$$

where $F_{s e c}-$ is the area of the front section of electrode melting with the shape of an ellipse with axes parameters

$$
a=\frac{d_{e l}}{2} \quad B=\frac{d_{e l}}{2 \sin \varpi} \quad(\text { Figure } 4)
$$

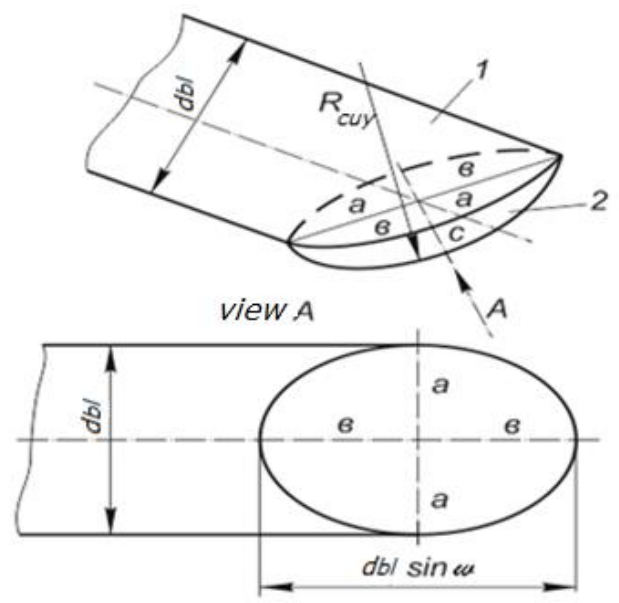

Fig. 4. An analytical model of the butt of a solid electrode for evaluation of $m_{\text {liqm }}$ 1 -is the electrode, 2 -the liquid metal on the butt of the electrode, a, 6 -axles of the semi-ellipsoid. then

$$
F_{s e c}=\pi a B=\frac{\pi d_{e l}^{2}}{4 \sin \varpi}
$$

or we may finally write that: 


$$
F_{s t .}=\frac{2,1 \cdot \pi \cdot d_{e l}^{2} \cdot\left(T_{c r}-T\right)}{2 \cdot\left(\mu \cdot \frac{1}{\gamma}\right)^{2 / 3} \cdot \sin \varpi \cdot R_{c u r}}
$$

For determination of the value of electrodynamic force which compresses the electrode and tries to separate the molten metal from it the method is applied, its essence being the following [7]:electrode's stick out distance and the arc are considered to be two conductors with $\mathrm{I}_{\text {arc }}$, current forming the system, its magnetic energy is equal to:

$$
W_{m}=\frac{\alpha I_{a r c}}{2},
$$

where $\alpha=\alpha_{1}+\alpha_{2}+2 M_{1,2}-$ general inductivity of the system (see Figure 4).

The electrodynamic force, tending to alter the mutual location of two conductors can be determined by changes in the energy of the magnetic system:

$$
F_{e l}=\frac{\partial W_{m}}{\partial x}=\frac{\mu_{0} \cdot I_{a r c}}{4 \cdot \pi} \ln \frac{R_{j}}{R_{e l}}
$$

where $\mu_{0}$ - being the absolute magnetic air permeability;

$R$ - the radius of the arc column.

It is obvious from the equation (12) that the electrodynamic force is in square dependence upon the arc current and is raised along with the increase of the diameter of its column and the decrease of the electrode's diameter. In [8] an expression for determination of the value of the electrodynamic force was proposed, which largely corresponds to the applied analytical model:

$$
F_{e l}=A I_{a r c}{ }^{2}\left(1+4,6 \cdot \lg \frac{r_{j}^{2}}{r_{e l}^{2}}\right)=A I_{a r c}{ }^{2}\left(1+2,3 \cdot \lg \frac{i_{e l}}{i_{j}}\right)
$$

where $A-$ is the coefficient, equal to $0.005 \mathrm{din} / \mathrm{A}^{2}$, according to the data, provided in [10]

$I_{\text {arc }}$ - the value of the arc current, A

$r_{j}-$ the radius of the arc column, $\mathrm{cm}$

$r_{e l}$ - the radius of the electrode, $\mathrm{cm}$

$i_{j}$ - current density of the arc column, $\mathrm{A} / \mathrm{cm}^{2}$

$i_{e l}$-current density on the electrode, $\mathrm{A} / \mathrm{cm}^{2}$

With regard to the analytical model, represented in Figure 4 for a solid electrode at arc metallization, for $P_{e l}$ we may write down through current densities:

$$
F_{e l}=A I_{a r c}^{2}\left(1+2,3 \cdot \lg \frac{i_{e l}}{i_{j}}\right)
$$

For solid electrodes the current density, according to the data provided in [8] will be determined through $r_{e l}$

$$
i_{e l}=\frac{I_{a r c}}{\pi r^{2}}
$$

The current density of the arc column will be determined on the basis of the model, Figure 4, according to A view we assume the arc column possesses the shape of an ellipse, with the bigger axle equal to $2 \boldsymbol{e}_{p o l}=2 \boldsymbol{\theta}_{e l} \cdot \cos \frac{\varpi}{2}$ and the smaller one equal to $2 a=d_{e l}$, thus, we have $\boldsymbol{B}_{p o l}=\frac{d_{e l}}{2 \sin \varpi} \cdot \cos \frac{\varpi}{2}$

Now we determine $\quad F_{j}=\pi a \boldsymbol{B}_{j}=\frac{\pi d_{e l}}{2} \cdot \boldsymbol{\theta} \cdot \cos \frac{\varpi}{2}=\frac{\pi r_{e l}^{2}}{\sin \varpi} \cos \frac{\varpi}{2}$

The current density in the arc column, with regard to the obtained expressions will be equal to: 


$$
i_{p o l}=\frac{I_{a r c} \sin \varpi}{\pi r_{e l}^{2} \cos \frac{\varpi}{2}}=\frac{2 I_{a r c} \sin \frac{\varpi}{2}}{\pi r_{e l}^{2}}
$$
our case:

By inserting the obtained expressions into the original equation (14) we will finally have for

$$
P_{e l}=A I_{\partial}^{2}\left(1+2,3 \cdot \lg \frac{1}{2 \sin \frac{\varpi}{2}}\right)
$$

I.e. we will get the equation for determination of the value of $P_{e l}$.

On the other hand, by assuming that on the butt of the electrode (at the first stage) the liquid metal has the shape of semi-ellipsoid, its maximal volume being equal to [9], Figure 4:

$$
v_{0,5 e l}=\frac{2}{3} \pi a \beta c
$$

where $a$-is the smaller half-axle of ellipsoid $a=\frac{d_{e l}}{2}=r_{e l}$

$$
B \text { - the bigger half-axle of ellipsoid } B=\frac{d_{e l}}{2 \sin \varpi}
$$

Applying the obtained expressions we can determine the value of half-axles of the semi-ellipsoid of the liquid metal on the butt of the electrode $\varepsilon$ and $c$ by means of thermalphysic melting indices and parameters of the sputtering mod, as the half-axle $a$ is a constant value, equal to a half of the electrode's diameter. Let us, now, establish the dependence:

$$
\boldsymbol{B}=\mathbf{f}\left(\mathbf{T}_{b}, \mathbf{T}_{\text {liqm }}, \mathbf{I}_{\text {arc }}, \gamma, M, \varpi\right) \cdot \boldsymbol{u} \cdot \boldsymbol{c}=f\left(\nu_{e l}, f, \varpi\right)
$$

For the case with the biggest quantity of liquid metal on the electrode's butt, preceding separation by means of $\mathrm{P}_{\mathrm{el}}$ it is possible to write down:

$$
P_{s t} \leq P_{e l}
$$

By inserting the value from equations (10) and (18) we will have:

$$
\frac{4,2 \cdot\left(T_{c r}-T\right) \pi \cdot a b}{\left(\mu \cdot \frac{1}{\gamma}\right)^{2 / 3} \cdot R_{c u r}} \leq A I_{\text {arc }}^{2}\left(1+2,3 \cdot \lg \frac{1}{2 \sin \frac{\varpi}{2}}\right)
$$

Having expressed $T_{c r}=\frac{3}{2} T_{b}$ we will obtain that 6 - the bigger half-axle of the ellipsoid will be determined from the equation:

$$
b=\frac{A I_{\text {arc }}^{2}\left(1+2,3 \cdot \lg \frac{1}{2 \sin \frac{\varpi}{2}}\right)\left(\mu \cdot \frac{1}{\gamma}\right)^{2 / 3} \cdot R_{c u r}}{2,1 \cdot \pi \cdot d_{e l} \cdot\left(1,5 \cdot T_{b}-T\right)}
$$

$c-$ is the second small half-axle of the ellipsoid.

The value of $c$ - can be determined as the thickness of the liquid layer at the discharge (pushing out) of the liquid metal from the electrode's butt. According to the data, provided in [9] the thickness of the liquid layer on the electrode's butt can be determined from this equation:

$$
l=\frac{v_{e l}}{f}
$$

where $v_{e l}$ - is the arte of feeding of dispersed electrodes, $\mathrm{cm} / \mathrm{sec}$; 
$f$ - the frequency of liquid metal discharging (determined according to oscillograms or shooting data). The discharging frequency can be taken with regard to the data, provided in [17], the discharging time at being equal to $t_{d i s}=5,73 \cdot 10^{-4} \mathrm{sec}$, then $f=\frac{1}{5,73} 10^{4}=0,174 \cdot 10^{4}=1740 \mathrm{rev} / \mathrm{sec}$.

$l$ value can fluctuate within the limits: $0 \prec l \prec c$

For evaluation of $c$ we have:

$$
c=l=\frac{v_{e l}}{f}
$$

By inserting the obtained expressions into the original equation (18) we'll get, with due regard to the fact that the liquid metal on the electrode's butt acquires the shape of a semi-ellipsoid $\left(V_{0,5 e l}\right)$

$$
v_{0,5 e l}=\frac{v_{e l} A I_{a r c}^{2}\left(1+2,3 \cdot \lg \frac{1}{2 \sin \frac{\varpi}{2}}\right)\left(\mu \cdot \frac{1}{\gamma}\right)^{2 / 3} \cdot R_{c u r}}{6,3 \cdot f\left(1,5 \cdot T_{b}-T\right)}
$$

The mass of the liquid metal pushed out upon the electrode's butt will be equal to (assuming that $m=v \cdot \gamma$ ) for a solid electrode

$$
m_{\text {liqm }}=\frac{A I_{\text {arc }}{ }^{2} v_{e l} \gamma\left(1+2,3 \cdot \lg \frac{1}{2 \sin \frac{\varpi}{2}}\right)\left(\mu \cdot \frac{1}{\gamma}\right)^{2 / 3} \cdot R_{c u r}}{6,3 \cdot f\left(1,5 \cdot T_{b}-T_{\text {liqm }}\right)}
$$

In the expression above the values represent physical characteristics of the electrode or parameters of the sputtering mode. The value $T_{\text {liqm }}$ can be found in literature $[7,8]$.

It is not difficult to see that $R_{c u r}=f\left(\varpi, b, c, d_{e l}\right)$, i.e. it depends upon the value of the liquid layer of the angle between the sputtered electrodes and the diameter of the sputtered electrodes, with regard to [7].

Applying the diagram pictured in Figure 4 we can determine:

$$
R_{c u r}=\frac{v_{e l}}{2 f \sin ^{2}\left(\operatorname{arctg} \frac{2 v_{e l} \sin \varpi}{f d_{e l}}\right)}
$$

Thus, we have received the equation that enable us to determine the radius of the curvature of liquid metal, depending upon the rate of electrodes feed, their diameter and the angle between them.

It follows from the data, contained in formula 26 that with growth of the angle between the electrodes $-\varpi-$ the value of the curvature radius decreases, it leading to an increase in the thickness of the liquid layer upon the butt, a similar influence has acceleration of the rate of electrode feeding as acceleration of the feeding rate, as a rule leads to an increase in mass of the molten electrode metal as well as in the thickness of the liquid layer.

An increase in the frequency of spills and in electrodes diameter leads to growth of the curvature radius of the surface of the liquid metal on the electrodes butts, it, probably, being connected with a decrease in the thickness of the liquid layer. The performed investigations showed that the obtained equation reflected actual conditions of electrodes melting and could be applied for calculations. By inserting the received value of $R_{\text {cuy }}$ from (26) into the original equation (25) and after rearranging it we will have:

$$
m_{\text {liqm }}=\frac{A I_{\text {arc }}{ }^{2} v_{e l} \gamma\left(1+2,3 \cdot \lg \frac{1}{2 \sin \frac{\varpi}{2}}\right)\left(\mu \cdot \frac{1}{\gamma}\right)^{2 / 3} \cdot R_{c u r}}{12,6 \cdot f^{2}\left(1,5 \cdot T_{b}-T_{\text {liqm }}\right) \sin ^{2}\left(\operatorname{arctg} \frac{2 v_{e l} \sin \varpi}{f d}\right)}
$$

where $\mathrm{A}-$ is a coefficient, equal to $0.005 \mathrm{din} / \mathrm{A}^{2}$ (the data obtained from [10]);

$I_{\text {arc }}$ - the value of arc current, A;

$\gamma$ - the density of electrode metal, $\mathrm{g} / \mathrm{cm}^{3}\left(\right.$ for $\mathrm{Fe}=7,6 \mathrm{~g} / \mathrm{cm}^{3}$ ); 
$\varpi-$ the angle between the sputtered electrodes, $\varpi=30^{\circ}$;

$f$ - the spills frequency, assumed to be, $f=1,100 \mathrm{sp} / \mathrm{sec}, t_{\text {dis }}=\frac{1}{1100}=9 \cdot 10^{-4} \mathrm{sec}$.(Al) or according to the data, provided in [17] $t_{c \sigma}=5,73 \cdot 10^{-4} \mathrm{sec}$ (for steel), $f=1740 \mathrm{sp} . / \mathrm{sec}$;

$\mu$ - intensity (26.9)

$T_{b}$ - boiling temperature $\left(-2,550^{\circ} \mathrm{K}, \mathrm{Al}-1000^{\circ} \mathrm{K}\right)$

$T_{\text {liqm }}$ - liquid metal temperature (for $\mathrm{Fe}-1,535^{\circ} \mathrm{C}$ )

$v_{e l}$ - electrode feeding rate, $\mathrm{cm} / \mathrm{sec}$ (the main rate $5 \mathrm{~cm} / \mathrm{sec}$ )

The obtained expression can be applied for determination of the mass of metal, accumulating on the electrode butt at arc melting.

It can be clearly seen from the determined expression (27) for evaluation of the mass of the liquid metal upon the butts of the electrodes that $m_{\text {liqm }}$ depends on the parameters of the mode of electric arc sputtering, the liquid metal temperature on the electrodes butts and properties of metal.

The results of calculations and graphical plotting are summarized in the nomogram of dependence of $m_{\text {liqm }}$ for electrodes the cathode and the anode upon the parameters of electric arc sputtering, pictured in figure 7. It can seen in the nomogram that with an increase in arc current the mass of liquid metal on the electrodes butts is increased at the same spillage frequency, it being caused by energy increase, generated in the arc. On the cathode the value of liquid metal is by $\approx 3,5 \cdot 10^{-6} \mathrm{~kg}$ greater than on the anode for electrodes $2 \mathrm{~mm}$ in diameter and by $\approx 5 \cdot 10^{-6} \mathrm{~kg}$ for electrodes $2.5 \mathrm{~mm}$ in diameter, this is likely to be caused by different temperature level. For optimal current values for electrodes $2 \mathrm{~mm}$ in diameter $\left(I_{\partial}=200 \mathrm{~A}\right)$ the value of liquid metal mass on the cathode is $m_{\text {liqm }} \approx 16,5 \cdot 10^{-6} \mathrm{~kg}$ and on the anode $m_{\text {liqm }} \approx 13,5 \cdot 10^{-6} \mathrm{~kg}$, for electrodes $2.5 \mathrm{~mm}$ in diameter $\left(I_{\text {arc }}=250 \mathrm{~A}\right)$ these values are $m_{\text {liqm }}=31,6 \cdot 10^{-6} \mathrm{~kg}$ and $m_{\text {liqm }}=28,4 \cdot 10^{-6} \mathrm{~kg}$ respectively. The level of values of liquid metal mass on the electrodes butts is increased with an increase of the electrode diameter.

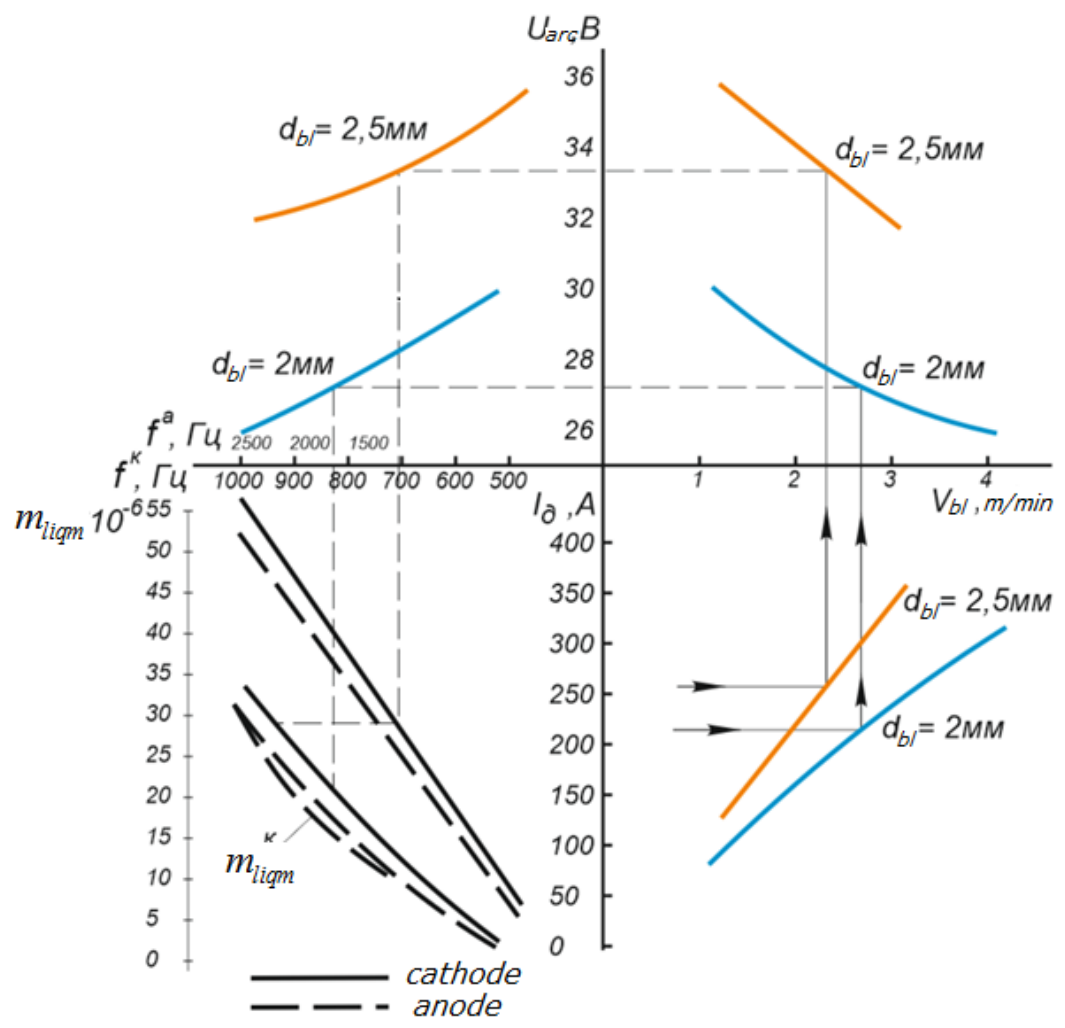

Fig. 5. Nomogram for evaluation of liquid metal mass on the butts of electrodes (anode and cathode) in dependence of the mode parameters of electric arc sputtering, the wire 06X18H9T $d_{b l}=2,0 ; 2,5 \mathrm{~mm}$. 
The dash-and-dot lines on the nomogram show the values liquid metal mass on the cathode. At the raised current values, when the spillage frequency of liquid metal is increased the value of the mass of liquid metal is less than on the anode at the equal mode parameters and is for electrodes $2 \mathrm{~mm}$ in diameter $I_{\text {arc }}=220 \ldots 320 \mathrm{~A} m_{\text {liqm }}=15 \ldots 34 \cdot 10^{-6} \mathrm{~kg}$.

This investigation does not take into account the influence of the spraying stream upon dispersity of the coating particles. Still, in [11,12,14,15 et al.] works there are expressions, that take into account the influence of the spraying stream upon the dimensions and mass of the sputtered material.

Represented below are the results of investigation of the frequency of pulsations of the spraying flow upon the particles dispersity, with the objective of determining the influence of the frequencies of pulsations of the spraying stream upon the value of particles mass:
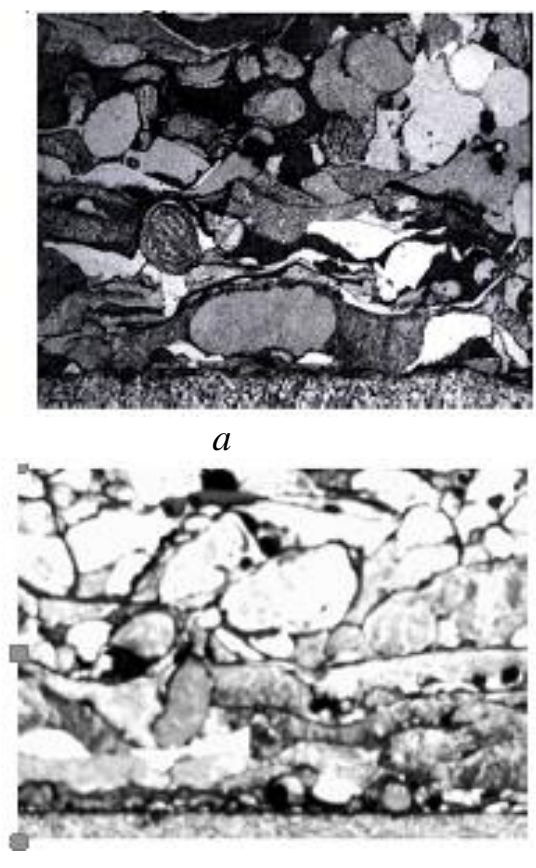

$c$

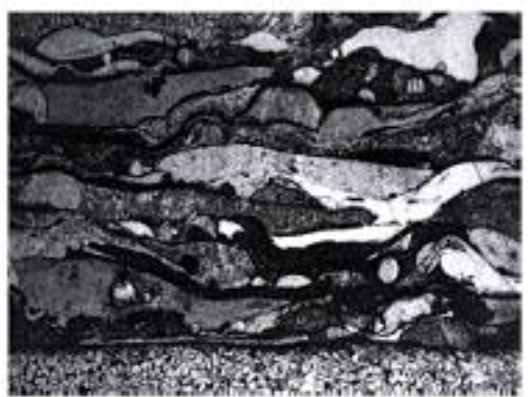

$b$

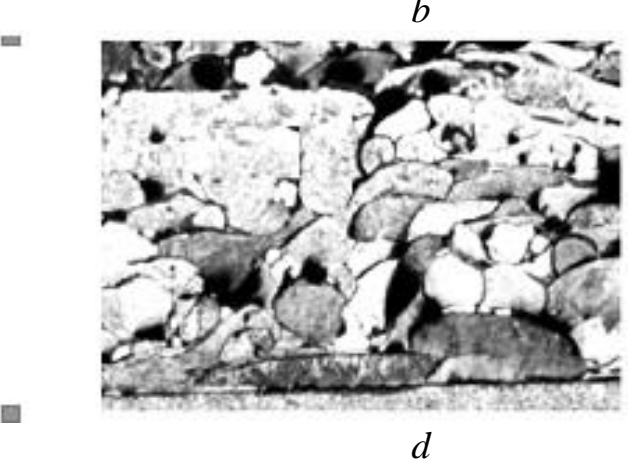

Fig. 6. The microstructure of coatings depending upon the number of pulsations of compressed air, $\times 50$ : a-without pulsations, $b$-pulsations equal to $43 \mathrm{~Hz}, c$-pulsations $65 \mathrm{~Hz}, d$-pulsations $105 \mathrm{~Hz}$ (powder wire ПП-МM-2)

The microstructure of coatings obtained at different frequency of the pulsating air-spraying jet with application of powder wire ПП - MM -2 is shown in Figure 6. It can be easily seen in the photographs that the coating microstructure is practically not changed when the number of pulsations is altered. The coating structure is not homogeneous when there are no pulsations in the air-spraying flow and has a lot of particles of different shape. Particles dispersity was also determined using the method, described in [16], by trapping the sprayed material in a vessel with water. The sprayed material was collected, dried and sieved through a set of sieves with different diameter of holes.

We determined the weight of each fraction in the experimental portion of the sprayed material

$$
n=\frac{M_{\exp }}{M_{f r}} 100 \%,
$$

where $M_{\text {exp }}$-is the material mass determined on the basis of the results of the experiment, in $\mathrm{g}$

$M_{f r}$ - the mass of fraction particles, $\mathrm{g}$

The experiments were conducted for jet pulsation frequencies $0,20,40,60,80,100,120 \mathrm{~Hz}$. The results of the fractional analysis for $10 Г 2 Ф Б$ steel grade are shown in Figure 7.

The character of changes in fractional particles dimensions at spraying of solid section wires is not essentially changed at approximately equal ratio of fractions $n$ for different frequencies, as energy indices of the material spraying remain unchanged as it was shown earlier. 


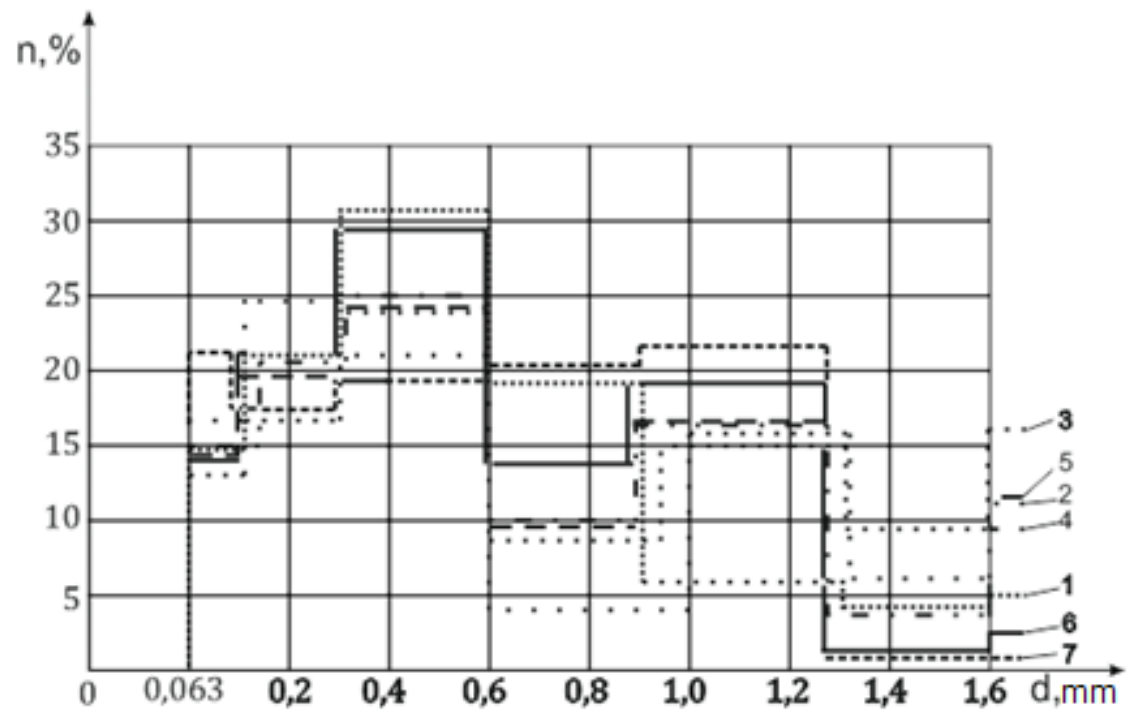

Fig. 7. The character of changes in particles dispersity of particles, depending on the frequency pulsations at EAM with application of a pulsing spraying jet, the sprayed material being -10Г2C

The represented results allow us to arrive at the conclusion that the energy of an electric arc is the factor determining the particles dispersity at electric arc sputtering with a pulsating spraying stream. At collecting of liquid metal on the butts of the sputtered electrodes, when $F_{s t} \leq F_{e l}$ the liquid metal due to the acting $F_{e l}$ is pushed into the sprayed air flow. At low frequencies $(20-30 \mathrm{~Hz})$ of air supply an increased collecting of liquid metal is possible in the absence of the flow acting, it leading to growth in particles dimensions or to a short circuit. At medium frequencies $(40-60 \mathrm{~Hz})$ the time of formation of liquid metal on the butts of the electrodes coincides with the frequency of impulses of the spraying stream, the dimensions of the particles being optimal, just like at impulse-free spraying. At increased frequencies the flow action apparently takes place when the liquid metal has not been accumulated yet during the pause and its tearing off with an air stream is done at the recurring (repeated several times) action of the spraying stream. At that the value of the mass of liquid metal is determined by the arc energy and no essential influence of the frequency of the pulsating stream upon the particles dispersity is supposed. It also should be taken into account that the level of the energy of the spraying stream is not changed, as the shape and size of the jet of the metallizer, gas temperature and pressure, flow conditions remain constant at pulsating electric arc sputtering.

\section{Conclusions.}

1. The method of melting of sprayed material is proposed at pulsating action of the sprayed stream as well as a scheme of electrodes butts action upon the liquid metal with and without air spraying flow.

2. It was found the level of electric arc energy at constant jet parameters and characteristics of gas flow was the critical factor for the coating particles dispersity.

3. Metallographic analysis and the methods of fixation of dispersed particles in a vessel with water allowed us to assert that at sputtering of wires with solid section application of a pulsating stream could not exert any essential influence upon the fractional composition of the sprayed material, as the mass of particles was determined mostly by energy indices of the electric arc.

\section{REFERENCES}

1. Роянов В.А., Бобиков В.В. Патент на корисну модель №95050 МПК /2014.01/В23К 9/00 Розпилююча головка для електродугової металлізації. Опубл.10.12.2014. Бюл.№23.

2. Роянов В.А. Устройство для электродуговой металлизации с пульсирующим режимом истечения воздушно-распыляющей струи /В.А. Роянов, В.И. Бобиков //Сварочное производство №4, 2015 c.12-15

3. Роянов В.А. Применение пульсирующей распыляющей струи при электродуговой металлизации / В.А. Роянов, В.И. Бобиков // Автоматическая сварка. - 2014. - № 6-7. - С. 128-131. - Режим доступу: http://nbuv.gov.ua/UJRN/as_2014_6-7_27

4. В.А. Роянов, В.И. Бобиков Разработка распыляющей головки для электродуговой металлизации с применением пульсирующей распыляющей струи. //Материалы НТК Сварочное производство в машиностроении, перспективы и развитие. Краматорск, ДГМА, 2010 
5. V. Royanov, I. Zakharova, E. Lavrova. Development of properties of spray flow and nature of pressure distribution in electric arc metalization // Eastern-European Journal of Enterprise Technologies, 6/5 (90) 2017, - C.41-49.

6. В.А. Роянов Влияние электродов на свойства распыляющей струи при электродуговой металлизации /В.А. Роянов, Г.А. Мосиенко // Сварочное производство №3,1990 с.6-8

7. Патон Б.Е. Автоматическое управление процессом дугвой сварки плавящимся электродом / Патон Б.Е., Шейко П.П. // Автоматическая сварка. - 1967. - № 1 - С. 3-8.

8. Дятлов В.И. Элементы теории переноса электродного металла при электродуговой сварке //Новые проблемы сварочной техники/ Киев: Техника 1964, с167-182

9. Пискунов П.С. Дифференциальные и интегральные исчисления (для ВУЗов). М: Наука, $1965547 \mathrm{c}$

10. Лесков Г.И. Пути повышения устойчивости высокопроизводительных сварочных дуг / Лесков Г.И., Заруба И.И. // Автоматическая сварка. - 1959. - № 12 - С. 34-42.

11. Митин Б.С. Порошковая металлургия и напыленные покрытия / Б.С. Митин М.: Машиностроение, 1987. - 791c.

12. Вахалин В.А. Исследование эффективности кпд нагрева электродов и коэффициента использования металла при электродуговой металлизации / В.А. Вахалин, В.В. Кудинов., В.Е. Белащенко. // Физика и химия обработки материалов №5,1981. С.65-67

13. Ерохин А.А. Кинетика Металлургических процессов дуговой сварки М.: Машиностроение, 1964. - 252c.

14. Коробов Ю. С. Кинетика взаимодействия напыляемого металла с кислородом при электродуговой металлизации/Ю.С. Коробов, В.Н. Бороненков / Сварочное производство 2003 - №7 с.30-36

15. Бороненков В.Н., Коробов Ю.С. Основы дуговой металлизации. Физико-химические закономерности. Монография // Издательство Уральского Университета, 2012, 260 стр.

16. Кудинов В.В. О температуре и скорости частиц при плазменном напылении / В.В. Кудинов, Н. Н. Рыкалин, М. Х. Шоршоров // Физика и химия. 